\title{
ASSESSING ROOTING MEDIA AND HORMONE ON ROOTING POTENTIAL OF STEM CUTTINGS OF BOUGAINVILLEA
}

\author{
P. Marasini* and A .Khanal \\ Lamjung Campus, Institute of Agriculture and Animal Science \\ "marasiniprakash055@gmail.com
}

\begin{abstract}
An experiment was conducted at Lamjung Campus, Lamjung to assess the rooting performance and bud sprouting of Bougainvillea, an evergreen ornamental vine. The study was conducted in partially controlled environment with two factorial treatments considering factor A in four levels(coco peat + sand, sand + FYM, garden soil, garden soil + FYM and garden soil )and factor B (with and without NAA 3000ppm) were arranged in completely randomized design (CRD) with three replication during September- November, 2016.18 cuttings having $15 \mathrm{~cm}$ in length with 4 buds were planted in each treatment. Root length $(7.83 \mathrm{~cm})$ found in Sand \& FYM was significantly different to other media but rooting percentage $(77.77 \%)$ was found statistically at par with other media except garden soil. Effect of hormone was found non-significant on total sprouted plant, sprout diameter and number of sprouts/cuttings whereas other parameters were affected significantly. Interaction effect of rooting media and hormone significantly affects root length $(11.6 \mathrm{~cm})$ and rooting percentage $(83.33 \%)$ which was found on sand \&FYM along with NAA 3000ppm followed by Garden soil \& FYM in combination with NAA 3000ppm while others parameters were non-significant. Thus it is advisable to use a good rooting media along with application of NAA 3000 ppm for better rooting in cuttings.
\end{abstract}

Keywords: Cuttings, NAA, root length, sprouting

\section{INTRODUCTION}

Bougainvillea, family Nyctaginaceae is a genus of thorny ornamental lush evergreen vine, bushes and trees with flower like spring leaves near its flower. It has a spreading, round plant habit with a height and spread of up to 20 feet which is mostly found in tropical and subtropical areas(Kobayashi et al.,2007).Flower color usually varies from white, Pink, Yellow and so on . Multiplication of ornamental plant is done by use of vegetative parts including terminal buds, stems, roots and leaves. Naphthalene acetic acid (NAA) is an important plant growth regulator which increases the availability of sugar at the site of root primoridium by increasing the mobilization of starch through increased activity of hydrolyzing enzymes which ultimately enhances root formation (Altman, 1972). Thus NAA can be a viable option to propagate Bougainvillea by stem cutting as it supports rapid multiplication of planting materials and have commercial value. Higher root formation can be attributed by higher water holding capacity and good aeration of rooting media. Mostly aeration is indeed for root development (Khayyat and Salehi, 2007). Different types of rooting media and their characteristics are utmost important for quality of rooted cuttings.t That's why combination of different rooting media and hormone can be viable option for conserving Bougainvillea spp and production of rooted cuttings.

\section{MATERIALS AND METHODS}

An experiment was carried out in polyhouse of Institute of Agriculture and Animal Science, Lamjung Campus, Nepal in two factorial viz. factor A in 1:1 (coco peat + sand, sand + FYM, soil + FYM and soil )and Factor B (no hormone and NAA 3000ppm) in completely randomized design (CRD) with three replication during the month of September- November, 2016. A healthy cultivar of single Sussex type was selected and a total of 144 cuttings of size $15 \mathrm{~cm}$ were planted in 8 tray (18 cuttings in each treatment). The cuttings were dipped for 10 seconds in NAA with 3000 ppm and 
the cuttings were placed on plastic tray with slanting position to control water deposition on upper surface. Different parameters were observed such as days to sprouting, total sprouted plants when the first sprout occured on cutting whereas sprout diameter, sprout length, number of sprout /cutting, dry matter/cutting, number of leaves per cutting, root length, rooting percentage and transplanting success percentage were observed after two months of planting the cutting. Data were analyzed using SPSS (Statistical Package for Social Science) Version 16 and Gen stat 15 Edition.

\section{RESULT AND DISCUSSION}

Maximum days to sprouting (10.33) were found statistically significant in soil whereas statistically at par in rest of media (table 1$)$. Maximum sprout length $(16.24 \mathrm{~cm})$ was found statistically significant in soil and FYM. This similar trend was also follow in number of leaves/cutting. In case of dry matter/cuttings cocopeat \&sand, sand\& FYM, Soil \& FYM were found statistically at par except soil .Effect of hormonal factor was found significant in all the variables except total sprouted plants. Maximum was found in NAA treated.

Table 1: Effect of different rooting media, hormonal role and their interaction with respect to different parameters in Lamjung, 2016

\begin{tabular}{|c|c|c|c|c|c|}
\hline Treatment & $\begin{array}{l}\text { Days to } \\
\text { sprouting }\end{array}$ & $\begin{array}{l}\text { Total sprouted } \\
\text { plants }\end{array}$ & $\begin{array}{l}\text { Sprout } \\
\text { length }(\mathrm{cm})\end{array}$ & cuttings $(\mathrm{cm})$ & $\begin{array}{l}\text { No.of leaves/ } \\
\text { cutting }\end{array}$ \\
\hline Cocopeat \&sand & $9^{\mathrm{ab}}$ & 5.67 & $7.83^{\mathrm{c}}$ & $1.54^{\mathrm{a}}$ & $21.29^{b}$ \\
\hline Sand \& FYM & $7.83^{\mathrm{b}}$ & 5.0 & $10.84^{\mathrm{b}}$ & $1.84^{\mathrm{a}}$ & $21.41^{\mathrm{b}}$ \\
\hline Soil \& FYM & $8.33^{\mathrm{b}}$ & 5.17 & $16.24^{\mathrm{a}}$ & $1.86^{\mathrm{a}}$ & $28.7^{\mathrm{a}}$ \\
\hline Soil & $10.33^{\mathrm{a}}$ & 4.83 & $9.63^{\mathrm{bc}}$ & $1.03^{\mathrm{b}}$ & $14.08^{\mathrm{c}}$ \\
\hline L.S.D & $1.767^{*}$ & 1.224 & $3.133 * *$ & $0.41 * *$ & $4.690 * *$ \\
\hline No hormone & $7.75^{\mathrm{b}}$ & 5.167 & $8.70^{\mathrm{b}}$ & $1.37^{\mathrm{b}}$ & $19.52^{\mathrm{b}}$ \\
\hline NAA 3000 ppm & $10.0^{\mathrm{a}}$ & 5.167 & $13.34^{\mathrm{a}}$ & $1.76^{\mathrm{a}}$ & $23.27^{\mathrm{a}}$ \\
\hline L.S.D & $1.24 * *$ & 0.865 & $2.21 * *$ & $0.29 *$ & $3.31 *$ \\
\hline $\mathrm{A} * \mathrm{~B}$ & NS & NS & NS & NS & NS \\
\hline L.S.D & 2.49 & 1.73 & 4.43 & 0.59 & 6.33 \\
\hline $\mathrm{CV} \%$ & 16.33 & 19.4 & 23.2 & 21.8 & 18.5 \\
\hline \multicolumn{6}{|c|}{$\begin{array}{l}\text { Note: Where * represents significant, ** represents highly significant, NS-non significant, } A * \\
\text { signifies interaction between } A \text { and } B\end{array}$} \\
\hline \multicolumn{6}{|c|}{$\begin{array}{l}\text { Table 2: Effect of different rooting media, hormonal role and their interaction with respect } t \\
\text { different parameters in Lamjung, } 2016\end{array}$} \\
\hline Treatment & $\begin{array}{l}\text { Sprout } \\
\text { diameter }(\mathrm{cm})\end{array}$ & No.of sprout & Root length( & Rooting $\%$ & $\begin{array}{l}\text { Transplanting } \\
\text { Success } \%\end{array}$ \\
\hline Cocopeat \&sand & $0.23^{\mathrm{b}}$ & $3.64^{\mathrm{a}}$ & $8.26^{\mathrm{b}}$ & $69.44^{\mathrm{a}}$ & 94.44 \\
\hline Sand \& FYM & $0.22^{\mathrm{b}}$ & $3.44^{\mathrm{a}}$ & $9.86^{\mathrm{a}}$ & $77.77^{\mathrm{a}}$ & 100 \\
\hline Soil \& FYM & $0.32^{\mathrm{a}}$ & $3.16^{\mathrm{a}}$ & $8.47^{\mathrm{b}}$ & $69.44^{\mathrm{a}}$ & 88.88 \\
\hline Soil & $0.19^{\mathrm{b}}$ & $2.16^{\mathrm{b}}$ & $4.30^{c}$ & $49.9^{b}$ & 100 \\
\hline L.S.D & $0.06^{* *}$ & $0.082 * *$ & $1.178 * *$ & $12.29 * *$ & 18.62 \\
\hline No hormone & 0.22 & 3.07 & $5.51^{\mathrm{b}}$ & $56.94^{\mathrm{b}}$ & $91.67^{\mathrm{b}}$ \\
\hline NAA 3000 ppm & 0.26 & 3.12 & $9.93^{\mathrm{a}}$ & $76.38^{\mathrm{a}}$ & $100^{\mathrm{a}}$ \\
\hline L.S.D & 0.04 & 0.59 & $0.833 * *$ & $8.83 * *$ & 13.17 \\
\hline$A * B$ & $0.23^{\mathrm{bcd}}$ & $2.22^{\mathrm{b}}$ & $8.10^{\mathrm{b}}$ & $72.22^{\mathrm{ab}}$ & 100 \\
\hline L.S.D & NS & NS & $* *$ & $*$ & NS \\
\hline CV\% & 0.24 & 3.09 & 7.72 & 66.66 & 95.83 \\
\hline
\end{tabular}

Note: Where ${ }^{*}$ represents significant, ${ }^{* *}$ represents highly significant, NS-non significant, $A{ }^{*} B$ signifies interaction between $A$ and $B$ 
Sprout diameter was found statistically significant. Maximum sprout diameter $(0.32 \mathrm{~cm})$ was found in soil and FYM whereas least diameter $(0.19 \mathrm{~cm})$ was found in soil (table 2). Number of sprout was found significantly different with respect to different media. Root length was found significantly different with respect to different media. Maximum root length $(9.86 \mathrm{~cm})$ was found in Sand and FYM whereas least root length $(4.30 \mathrm{~cm})$ was found in soil. Rooting percentage was also found significantly different with media. Cocopeat \& Sand, Sand \& FYM, Soil \& FYM were statistically at par in rooting percentage. Effect of hormonal factor was found significant on root length and rooting percentage. Maximum was found in NAA treated cuttings.

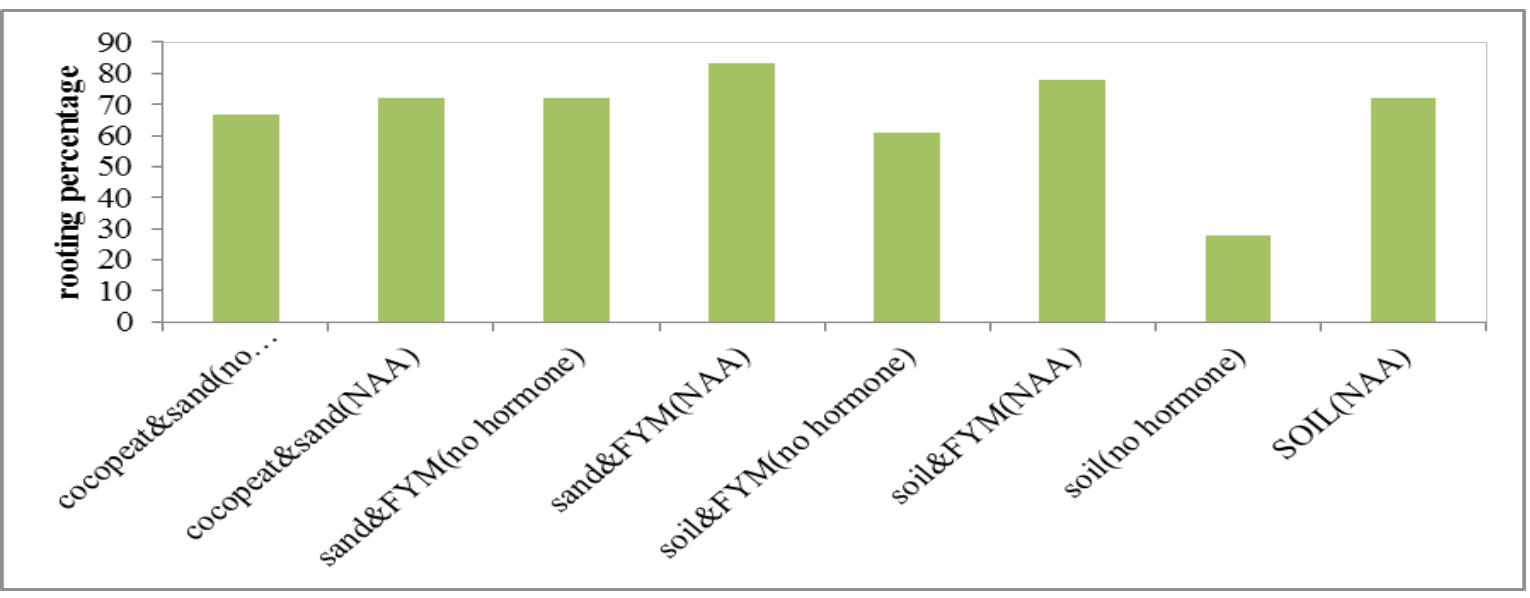

Figure:1 Interaction between media and hormone on rooting percentage

Interaction effect between rooting media and hormone was found significantly different on root length and rooting percentage. From figure 1, it can be stated that highest percentage of rooting was found in Sand \& FYM with NAA 3000ppm (83.33\%) which was statistically at par with all the interactions except with that of Soil \& FYM without hormone and soil without hormone applications. The least rooting percentage $(27.77 \%)$ was found in soil without hormone applications.

From figure 2, it can be stated that root length was found significantly different with respect to different media and hormone interactions.

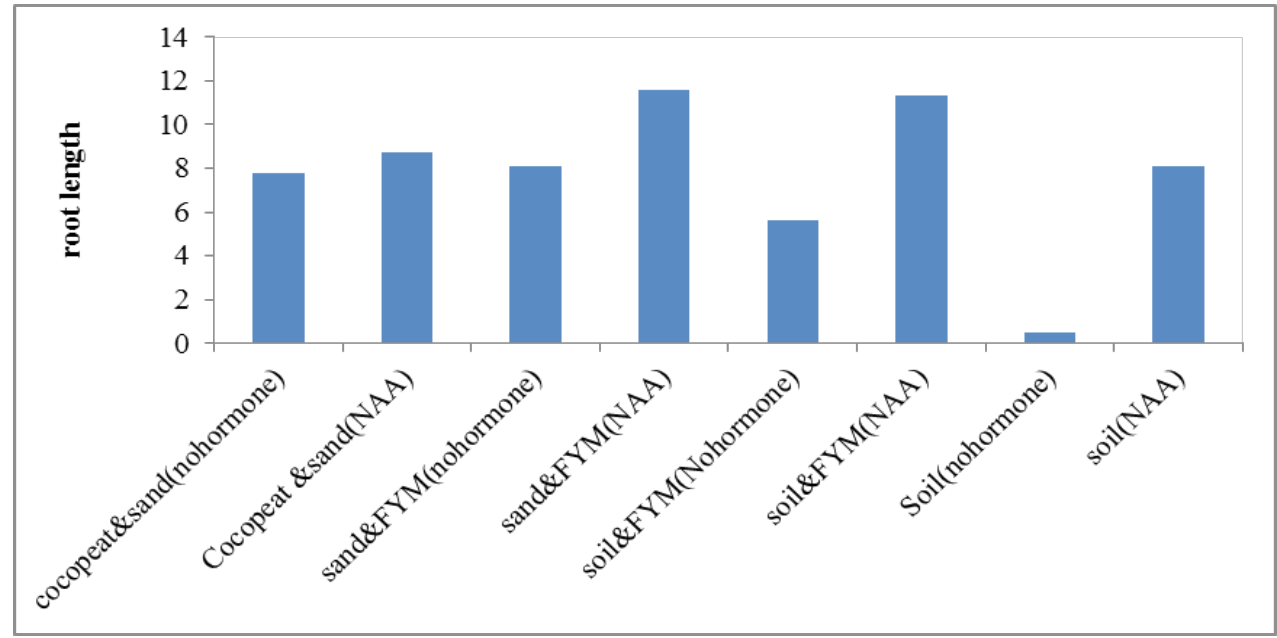

Figure 2: Interaction between media and hormone on root length 
Longest root length $(11.6 \mathrm{~cm})$ was found in sand\& FYM with NAA 3000 ppm while least root length $(0.5 \mathrm{~cm})$ was found in soil without hormone. Root length in Coco peat $\&$ sand without hormone, with NAA 3000ppm, sand\& FYM without hormone and soil with NAA was found statistically at par.

Due to simplicity and practiablility of vegetative propagation, this method of propagation has been mostly used in stem cuttings of Bougainvillea. However the rooting rate of success is very low and varies from species to species. Due to limited rates of success in sprouting and rooting, many researchers tried various auxins for initiation of rooting in cuttings of various horticultural crops as reported by (Sherer et al., 1985). Sprouting of cutting mainly depends on higher carbohydrate accumulation, portion of cutting, species.

Leaky et al., (1982) also found leaf mold medium which had maximum number of leaves as a result of the high organic matter content which increased the water and nutrient holding capacity of the medium. As soil and FYM have high water and nutrient holding capacity and high organic matter content. Soil \& FYM has ability to produce more number of leaves due to additional amount of nutrients from both of it i.e soil and FYM. Sprout diameter is further linked to amount of organic matter content in the media as soil \& FYM provides more amount of nutrient which helps to increase the sprout diameter.

Fagge et al., (2011) also reported that influence of medium is felt before rooting occurs due to water retention and aeration properties which ultimately increase percentage, length and quality of roots. According to Strydem and Hartman (1960), the increase in length of roots in cuttings treated with growth regulators may be due to the accumulation of metabolites at the site of application of auxins, cell enlargement, enhanced hydrolysis of carbohydrates, synthesis of new proteins, and cell division. Puri and Verma (1966) also stated that better rooting is due to better aeration as aeration helps in root respiration which encourages aerobic root respiration which ultimately yields 36 ATP of energy.

\section{CONCLUSION}

Rooting media shows considerable effect on root, shoot development and growth of cuttings. NAA 3000 ppm enhances rooting in the cuttings .That's why combination of Sand \& FYM and NAA $3000 \mathrm{ppm}$ can be viable option for production of rooted cuttings. Thus which ultimately reduces the import of Bougainvillea rooted cuttings from India and conserves the Bougainvillea spp for future.

\section{ACKNOWLEDGEMENT}

The authors would like to express deepest gratitude to Lamjung Campus, Institute of Agriculture and Animal Science. Moreover, we are indebted to Dr. Umed Pun for giving the ideas and other support too. We would like to thank Standard Nursery for providing cocopeat for research and all the helping hands.

\section{REFERENCES CITED}

Altman, A.(1972). Role of Auxin in root initiation in cuttings. Proceedings of international Plant Propagation Society, London, 22: 284-294.

Fagge, A. \& Manga, A.(2011). Effect of sowing media and gibberellic acid on the growth and seedling establishment of Bougainvillea glabra, Ixora coccinea and Rosa chinensis characters 2; Root characterization . Bayers J. Pure Applied Sci 4(2):155-159. 
Khayyat, M., \& Salehi, S.(2007). Effects of different pot mixtures on Pothos (Epipremnun aureum Lindl. and Andre 'Golden Pothos') growth and development. American-Eurasian Journal Agriculture Environment Science, Deira, 6, 3: 360-371.

Kobayash, K. D., Connell, J. \& Griffis, J. (2007). Buogainvillea Cooperation Extension Service. College of Tropical Agriculture and Human Resources. University of Hawaii at Manoa. Ornamental and Flowers. $145 \mathrm{p}$.

Leaky, R.R.B., Charman, V.R., \& Longman, K.A. (1982). Physiological studies for tree improvement and conservation. Factors affecting root initiation in cuttings of Triplochitonscleroxylon K. Schum. Forest Ecology and management, 4: 53-66.

Puri, S. \& Verma, R.C.(1996). Vegetative propagation of Dalbergia sisoo Roxb using softwood and hardwood cuttings J. Arid Environments,34:235-245.

Sherer, V. K., Gadiev, R.S., Vorobeva, A.F., \& Salun, N.I.(1985). Growth regulating activity of various chemical compounds grapevine rootstock cuttings.Vin. Org. AdarsalvaiVinodelie, 28:12-15.

Strydem, D. K., \& Hartman, H.T.(1960). Effect of indole butyric acid and respiration and nitrogen metabolism Marianna 2624 plum softwood stem cuttings. Proceedings of American Society of Horticulture, 45(1- 2): 81-82. 